\title{
Association of tomato leaf curl New Delhi virus DNA-B with bhendi yellow vein mosaic virus in okra showing yellow vein mosaic disease symptoms
}

\author{
V. VENKATARAVANAPPA ${ }^{1,2,3^{*}}$, C. N. LAKSHMINARAYANA REDDY' ${ }^{4}$ S. JALALI ${ }^{1}$, M. KRISHNA REDDY ${ }^{1 *}$
}

${ }^{1}$ Indian Institute of Horticultural Research, Hessaraghatta Lake PO, Bangalore-560089, Karnataka, India; ${ }^{2}$ Indian Vegetable Research Institute, Varanasi-221305, Uttar Pradesh, India; ${ }^{3}$ Department of Plant Pathology, Agriculture College, GKVK Campus, University of Agricultural Sciences (B), Bangalore-560065, Karnataka, India; ${ }^{4}$ Department of Plant Pathology, College of Sericulture, University of Agricultural Sciences (B), Chintamani-563125, Karnataka, India

\begin{abstract}
Summary. - Okra samples showing yellow vein mosaic, vein twisting and bushy appearance were collected from different locations of India during the surveys conducted between years 2005-2009. The dot blot and PCR detection revealed that $75.14 \%$ of the samples were associated with monopartite begomovirus and remaining samples with bipartite virus. Whitefly transmission was established for three samples representing widely separated geographical locations which are negative to betasatellites and associated with DNA-B. Genome components of these three representative isolates were cloned and sequenced. The analysis of DNA-A-like sequence revealed that three begomovirus isolates shared more than $93 \%$ nucleotide sequence identity with bhendi yellow vein mosaic virus from India (BYVMV), a monopartite begomovirus species that was reported previously as causative agent of bhendi yellow mosaic disease in association of bhendi yellow vein mosaic betasatellite. Further, the DNA-B-like sequences associated with the three virus isolates shared no more than $90 \%$ sequence identity with tomato leaf curl New Delhi virus (ToLCNDV). Analyses of putative iteron-binding sequence required for trans-replication suggests that begomovirus sequences shared compatible rep-binding iterons with DNA-B of ToLCNDV. Our data suggest that the monopartite begomovirus associated with okra yellow vein disease has captured DNA-B of ToLCNDV to infect okra. Widespread distribution of the complex shows the increasing trend of the capturing of DNA-B of ToLCNDV by monopartite begomoviruses in the Indian subcontinent. The recombination analysis showed that the DNA-A might have been derived from the inter-specific recombination of begomoviruses, while DNA-B was derived from the ToLCNDV infecting different hosts.
\end{abstract}

Keywords: PCR; begomovirus; yellow vein mosaic; recombination; whitefly; phylogeny

\section{Introduction}

Geminiviruses (the family Geminiviridae) are plant viruses with genome of small circular single-stranded DNA

*Corresponding authors. E-mail: venkatrajani@gmail.com,

mkreddy.iihr@gmail.com; phone: +91-80-28466420 (Extn. 272).

Abbreviations: $\mathrm{ACMV}=$ African cassava mosaic virus; $\mathrm{BYVB}=$ bhendi yellow vein betasatellite; BYVDV = bhendi yellow vein Delhi virus; BYVMV = bhendi yellow vein mosaic virus; CLCu$\mathrm{MuV}=$ cotton leaf curl Multan virus; $\mathrm{CR}=$ common region; $\mathrm{IR}=$ intergenic region; $\mathrm{MeYVMV}=$ mesta yellow vein mosaic virus; $\mathrm{NSP}=$ nuclear shuttle protein; Rep = replication associated protein; SLCCNV = squash leaf curl China virus; ToLCNDV = tomato leaf curl New Delhi virus with geminate isometric particle morphology. These are found in tropical to warm temperate geographical zones and infect a wide range of plants including crops, native weeds and wild plants (Morales and Anderson, 2001). Geminiviruses are classified into four genera based on insect vector involved in transmission and genome organization. The genus Begomovirus is the largest genus of geminiviruses transmitted by whitefly, Bemisia tabaci. Begomoviruses have emerged everywhere in the world where environmental conditions support large populations of $B$. tabaci and have become a major threat for the production of food and fiber crops (Varma and Malathi, 2003).

Geminiviruses have either bipartite (DNA-A or DNA-B) or monopartite (equivalent of DNA-A) genomes, with the 
A component encoding 5-7 proteins and the B component encoding two proteins, each component being $2.5-2.8 \mathrm{kbp}$ in size. The DNA-A component is capable of autonomous replication and can produce virus particles that encode proteins responsible for particle encapsidation (V1), viral replication (C1 and $\mathrm{C} 3$ ), regulation of gene expression and suppression of host defense mediated by gene silencing (C2). Modulation of symptom development and suppressor of gene silencing was attributed to the protein encoded by $\mathrm{C} 4$ gene of begomoviruses originating from the Old World. The New World begomoviruses lack an ORF termed V2 but it is found in begomoviruses originating from the Old World. The V2 is involved in movement and pathogenicity. The ORF BV1 and $\mathrm{BC} 1$ located on DNA-B component encode two proteins involved in intracellular (nuclear shuttle protein- NSP) and intercellular (movement protein, MP) virus movement (Lazarowitz, 1992). The two components of begomoviruses have only a little sequence homology except for an intergenic region (IR), which includes the common region (CR) of approximately 200 nucleotides with typically more than $85 \%$ identity between DNA-A and DNA-B. The CR contains a highly conserved (among geminiviruses) hairpin structure with the characteristic nonanucleotide sequence (TAATATTAC) that marks the origin of virion-strand DNA replication (Hanley-Bowdoin et al.,1999) and repeated sequences (collectively known as "iterons") required for the binding of the Rep protein (Arguello-Astorga et al., 1994) and regulatory regions for bidirectional transcription. The CR thus functions in integrity maintenance of the divided genome and in ensuring the replication of both components initiated by the DNA-A-encoded Rep protein (Briddon et al., 2010).

Recombination and pseudorecombination are very frequent and widespread phenomenon that occur between species as well as within or across genera, and are significant contributors to geminivirus evolution. Recombination is the exchange of DNA between similar DNA components, and pseudorecombination is the exchange of whole genome components between the viruses (Polston and Anderson, 1997). The evolution of virulent viral strains by recombination mechanism can have devastating consequences on the host population structure and skiping of evolved novel virus to the new host species (Padidam et al., 1999). High diversity among begomovirus species associated with mixed infections may be the major facilitator for the recombination and pseudorecombination events, leading to the frequent emergence of new begomoviruses (Jeske et al., 2001; Schnippenkoetter et al., 2001). Recent studies of begomovirus populations from the Indian subcontinent revealed their evolutionary divergence as a new group of begomoviruses, distinct from other begomoviruses causing similar diseases in other geographical regions of the world (Lefeuvre et al., 2007).

Yellow vein mosaic disease of okra caused by a begomovirus complex has became major constraint for okra cultivation and production in the Indian subcontinent (Jose and Usha, 2003; Venkataravanappa et al., 2012a,b, 2013a,b). The first record of the disease was from Bombay in India (Kulkarni, 1924) and subsequently named as "yellow vein mosaic of okra" (Uppal et al. 1940). Further, based on its morphology and serological relation with African cassava mosaic virus (ACMV), a geminivirus was shown to be associated with the disease (Harrison et al., 1999). The economic losses caused by this disease were 50 to $90 \%$, depending on stage of the crop growth at which infection occurred (Sastry and Singh, 1974; Sinha and Chakrabarthi, 1978). Symptoms of the disease include yellow mosaic, vein thickening, vein twisting, petiole bending, complete yellowing, yellowing with upward curling and stunted plant growth. The disease is transmitted by whitefly in a circulative persistent manner. Recently betasatellite of yellow vein mosaic disease of okra has been identified in samples collected from south India and Koch's postulate has been proved by agroinculation of BYVMV and bhendi yellow vein betasatellite (BYVB) on okra (Jose and Usha, 2003).

The surveys for begomovirus associated diseases in okra fields in India during 2005-2009 revealed wide spread infection with yellow vein mosaic disease with highly variable symptoms, making difficulty in visual identification of the disease-associated begomoviruses. Here, we characterized the new BYVMV isolates causing yellow vein mosaic disease of okra collected from three different geographical locations of India, which are associated with the DNA-B-like sequence of ToLCNDV.

\section{Materials and Methods}

Collection of symptomatic samples and maintenance of virus isolates. Totally, 173 okra leaf samples were collected from the plants exhibiting yellow mosaic, vein thickening, petiole bending, complete yellowing, upward curling with yellowing and stunted growth symptoms. The geographical locations comprised of nine states and two union territories representing India. Among these, one sample each from Haryana, Tamil Nadu and Karnataka were further characterized and were designated as BYVMV isolates OY77B, OY174 and OY-T, respectively. Two samples of non-symptomatic plants from each location were also collected. All the samples were stored at $-80^{\circ} \mathrm{C}$ for further studies and 55 samples representing different geographical regions (11) were used for whitefly transmission.

Nucleic acid hybridization for detection of virus - synthesis of DNA probe. The pTZ57R vector (Fermentas) containing the CP gene and betasatellite clones of BYVMV (OY Kaiwara, Acc. No. GU112057 \& GU111976) and NSP gene of DNA-B-like sequence of ToLCNDV (OY-T, Acc. No. HQ586005) were double digested with EcoRI and PstI. The digested DNA fragments were electrophoresed in $1 \%$ low melting agarose gel and then the fragments were purified using QIAquick gel extraction kit (QIAGEN Inc., USA). Labeling 
was done using random primed labeling with DIG-High prime kit II (Roche diagnosis, Germany). The probes were stored at $-20^{\circ} \mathrm{C}$ until further use.

Hybridization and colorimetric staining. Hybridization protocol was done according to Dietzgen (1997). The nucleic acid of yellow vein mosaic virus infected samples were spotted (10 $\mu \mathrm{l}$ sample/ spot) directly on the nitrocellulose membrane. The DNA was fixed on the membranes by UV cross linking for 3 min. Membrane was subjected to pre-hybridization, hybridization and detection procedures according to the manufacturer's instructions (DIG High Prime DNA labeling and detection starter kit II). Colorimetric based detection was employed with the use of nitroblue tetrazolium (NBT) and X-phosphate. The reaction was considered positive when purple color developed on the nitrocellulose membrane where the samples were spotted.

Whitefly transmission. Three samples designated as OY77B, OY174 and OY-T isolates were subjected to transmission studies. The collection and maintenance of whiteflies and transmission studies were done as described by Venkataravanappa et al. (2012a). After inoculations, the plants were sprayed with insecticide and maintained under insect-proof glasshouse for symptom expression. Leaf samples from the plants showing symptoms were utilized for further studies.

DNA isolation. Total DNA was isolated from the infected leaves collected from the plants maintained under controlled conditions (all 173 samples) using cetyl trimethyl ammonium bromide method (Doyle and Doyle, 1990). The total nucleic acid, isolated from the leaves of healthy okra plants (cv. 1685) grown under identical conditions were used as a control.

PCR amplification. The full length genomes (DNA-A and DNA-B like-sequence) of begomoviruses were PCR amplified using three sets of degenerate overlapping primers for each genome as described by Venkataravanappa et al. (2012a). In order to rule out the mixed infections, these primers were designed with a significant length of sequence overlapping (approximately $200 \mathrm{bp}$ ) between the segments. The DNA-A amplification was performed with 35 cycles with cycling conditions of denaturation for $1 \mathrm{~min}$ at $94^{\circ} \mathrm{C}$, primer annealing for $45 \mathrm{sec}$ at $55^{\circ} \mathrm{C}$ to $58^{\circ} \mathrm{C}$, and primer extension for 90 sec at $72^{\circ} \mathrm{C}$, with an initial denaturation at $94^{\circ} \mathrm{C}$ for $3 \mathrm{~min}$ and a final extension for $15 \mathrm{~min}$ at $72^{\circ} \mathrm{C}$. The PCR reactions were carried out in a Gene Amp PCR system 9700 (PE Applied Biosystems, USA) thermocycler. PCR reactions were carried out in a volume of $25 \mu \mathrm{l}$ containing $100 \mathrm{ng}$ of DNA template, $0.5 \mathrm{U}$ Taq DNA polymerase (Fermentas, Germany), $2 \mathrm{mmol} / \mathrm{l} \mathrm{MgCl}_{2}$ (Fermentas, Germany), $0.16 \mathrm{mmol} / \mathrm{l} \mathrm{dNTPs}$ (Fermentas, Germany) and $0.3 \mu \mathrm{mol} / \mathrm{l}$ of each primer. PCR products were electrophoresed ( $1 \mathrm{hr}$ at 80 volts) in $0.8 \%$ agarose gel in Tris-borate-EDTA buffer, $\mathrm{pH}$ 8.0. Gels were stained with ethidium bromide $(10 \mathrm{mg} / \mathrm{ml})$ and were visualized and documented by Alpha digidoc1000 system (Alpha Innotech Corporation, USA). The same PCR conditions were used for DNA-B except for primer annealing which was performed at $58^{\circ} \mathrm{C}$ for $1 \mathrm{~min}$. For amplification of betasatellites, universal betasatellite primers (Briddon et al., 2002) were used. Amplifications with samples from non-symptomatic plants and healthy plants were used as a negative control.

Cloning and sequencing. The amplified products of both DNA-A and DNA-B-like sequences were purified and cloned into the plasmid vector $\mathrm{pTZ} 57 \mathrm{R} / \mathrm{T}$ using Ins T/A clone PCR product cloning kit (Fermentas Life Sciences, USA) according to the manufacturer's instructions. Three clones from each transformation (DNA-A and DNA-B) were sequenced by automated DNA sequencer ABI PRISM 3730 (Applied Biosystems) from Anshul Biotechnologies DNA sequencing facility, Hyderabad, Andhra Pradesh, India.

DNA sequence analysis. The comparison of DNA-A and DNAB-like sequences of begomovirus isolates from okra was done with selected begomovirus sequences retrieved from database (NCBI). Sequence identity matrixes for the begomoviruses were generated using Bioedit sequence alignment editor (version 5.0.9) (Hall, 1999) and phylogenetic tree was generated by MEGA 5.0 software using the neighbor joining method with 500 bootstrapped replications (Tamura et al., 2011).

Detection of recombination events. This was carried out using the selected begomoviruses accessions reported from India and the Indian subcontinent that are available in the GenBank. The conflicting phylogenetic signals were detected using program split tree version 4.11.3 with default settings (Huson and Bryant, 2006). Further, recombination analysis was carried out using recombination detection program (RDP), GENECOV, Bootscan, Max Chi, Chimara, Si Scan, 3Seq which are integrated in RDP3 to detect the recombination break points (Martin et al., 2010). Default RDP settings with 0.05 P-value cut-off and standard Bonferroni correction were used.

\section{Results}

\section{Dot blot and PCR detection of begomoviruses}

All the 173 okra samples showing different types of virus disease symptoms collected from different geographical regions of India during field survey, positively reacted with the CP gene probe of BYVMV DNA-A-like sequence. Forty three samples reacted positively to NSP gene probe of DNAB-like sequence of BYVMV (OY-T) and 130 samples reacted positively for betasatellite DNA. Further evidence for these results was provided by PCR detection reproducing the same results (data not shown). Dot blot and PCR detection together, revealed that $75.14 \%$ of the samples were associated with monopartite begomovirus and remaining samples with bipartite virus. Amplification with nucleic acid extracts from healthy control plants was negative. These results have indicated the prevalence of both monopatite and bipartite begomoviruses across different geographical regions of India in okra with more samples skewed towards monopartite viruses. Characterization of three representative virus isolates, 
which are geographically widely separated and positive for detection of bipartite genome components, was done.

\section{Disease transmission by whitefly}

Total 100 seedlings of okra (cv1685) were inoculated for each isolate (OY77B, OY174 and OY-T) using whitefly (10 whiteflies/seedling). All inoculated seedlings showed symptoms of yellow vein mosaic with minimum incubation period of 8-10 days in OY174 \& OY-T and 10-12 days in OY77B and as the days advanced the leaf coloration became intense yellow with burning of leaf tips and plants failed to produce fruits. All these symptoms were similar to those observed on the field infected plants. The transmission tests were highly successful as infection rate was $100 \%$ on tested okra susceptible seedlings.

\section{Genome amplification}

The complete genome of DNA-A- and DNA-B-like sequences of begomovirus isolates (OY77B, OY174 \& OY-T) were amplified by using six sets of primers in the samples showing yellow vein mosaic disease but were negative for BYVB in both field samples and whitefly inoculated samples. When sequences of both field and whitefly inoculated samples were compared, they were identical and, therefore preceded with representative sequences for further analysis.

Genome organization and sequence analysis of DNA-Alike sequence

The complete DNA-A-like sequences of the begomovirus isolates (OY77B, OY174 and OY-T) were determined in both orientations and were ranged from 2720-2746 nts in length and are available in the NCBI database (Acc. No. JQ326263, GU112073, GU112049 respectively). The comparison of complete nucleotide sequences of DNA-A-like sequence of begomovirus isolates (OY77B, OY174 and OY-T) with other selected begomovirus sequences revealed that all the three begomovirus isolates share more than $94 \%$ nucleotide sequence identity with BYVMV (Table $1 \mathrm{~A}$ ) indicating that OY77B, OY174 and OY-T are isolates of BYVMV. These results were well supported by a phylogenetic analysis which shows OY174, OY-T and OY77B grouped with BYVMV for which a full-length sequence is available in the database (Fig. 1a).

The clones of begomoviruses showed typical genome organization of the Old World begomoviruses with the presence of stem-loop structure within an intergenic region (IR) and seven conserved genes (the coat protein (CP) and precoat protein (V2) in the virion sense and the replication associated protein (Rep), trans-activating protein ( $\mathrm{TrAp}$ ), replication enhancer (REn), C4 and C5 in complementary sense) with the capacity to encode proteins of predicted molecular mass of $11.05 \mathrm{kDa}$ or more. The main genetic features of these begomovirus sequences are given in Table 2. In the seven ORFs, among the three begomoviruses, small differences were noted in the start and stop codon and in the number of amino acids encoding the Rep protein.

Comparison of individually encoded proteins of begomovirus isolates OY174 and OY-T with other begomoviruses revealed that all the regions, $\mathrm{CP}(\mathrm{V} 1)$, pre-coat (V2), Rep (C1), TrAP (C2), REn (C3), C4 and C5 shared maximum amino acid identity with BYVMV. The isolate OY77B shared the maximum amino acid identity with BYVMV in the Pre-coat, REn, TrAP and $\mathrm{C} 4$ regions. In the $\mathrm{CP}$ region

Table 1A. Pairwise percentage of nucleotide identities between the genomic components from begomoviruses (OY77B, OY-T and OY174) isolated from okra and selected other begomoviruses available in the databases

\begin{tabular}{|c|c|c|c|c|c|c|}
\hline \multirow{2}{*}{ Begomoviruses\# } & \multicolumn{2}{|c|}{ OY77B } & \multicolumn{2}{|c|}{ OY-T } & \multicolumn{2}{|c|}{ OY174 } \\
\hline & Genome & IR & Genome & IR & Genome & IR \\
\hline BYVMV-okra $(35)^{*}$ & $\underline{82.7-94.4}$ & 63.7-98.1 & $\underline{83.1-95.1}$ & $\underline{70.5-98.1}$ & $\underline{84.0-98.8}$ & $\underline{54.8-98.1}$ \\
\hline CLCuMV-Cotton(11) & $85.5-90.0$ & $57.0-97.0$ & $81.9-86.3$ & $56.0-96.3$ & 81.6-85.7 & $48.5-81.8$ \\
\hline CLCuShV-Cotton (4) & $82.4-82.7$ & $67.4-68.1$ & $78.8-79.9$ & $67.8-68.5$ & $77.7-78.2$ & $59.6-60.3$ \\
\hline MeYVMV-Mesta (10) & $80.6-86.0$ & $57.4-66.7$ & $78.0-85.2$ & $57.5-66.7$ & $76.6-83.5$ & $57.2-59.0$ \\
\hline ToLCNDV-Okra (5) & $72.1-74.6$ & $57.5-58.9$ & $70.7-72.7$ & $58.5-59.9$ & $70.1-72.8$ & $50.2-51.4$ \\
\hline OYVMV-201 (1) & 90.6 & 62.3 & 89.4 & 62.7 & 88.2 & 54.2 \\
\hline CLCuRV-Cotton (1) & 86.5 & 65.9 & 83.2 & 66.3 & 82.1 & 55.5 \\
\hline CLCuBaV-Cotton (1) & 72.9 & 72.9 & 82.6 & 72.9 & 83.0 & 65.0 \\
\hline ToLCNDV-AVT1-Tomato (1) & 72.3 & 56.5 & 70.7 & 57.8 & 70.1 & 49.7 \\
\hline ToLCNDV-Chilli (1) & 72.0 & 55.8 & 70.6 & 57.1 & 70.0 & 49.1 \\
\hline ToLCNDV-Papaya (1) & 71.0 & 51.0 & 69.3 & 52.0 & 68.7 & 44.6 \\
\hline ToLCNDV-[Lucknow] (1) & 71.6 & 55.1 & 70.5 & 56.1 & 69.9 & 48.2 \\
\hline ToLCNDV-Luffa (1) & 72.3 & 54.1 & 71.2 & 55.1 & 70.3 & 47.6 \\
\hline
\end{tabular}

${ }^{\star}$ Numbers of sequences from the databases used in the comparisons. IR = intergenic region. \#The abbreviations of the species are under Fig. 1 . For each column the highest nucleotide identity value is underlined. 


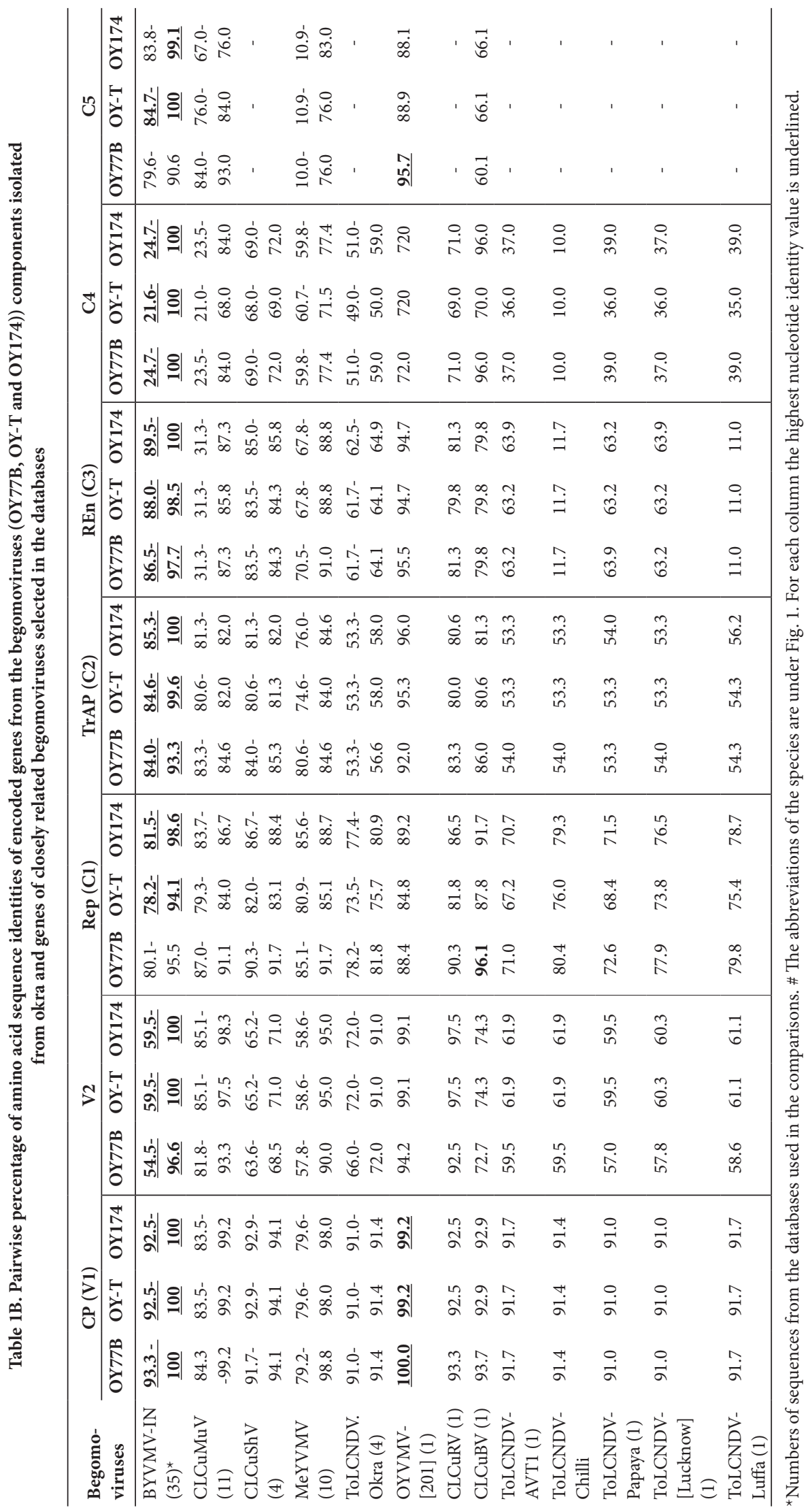




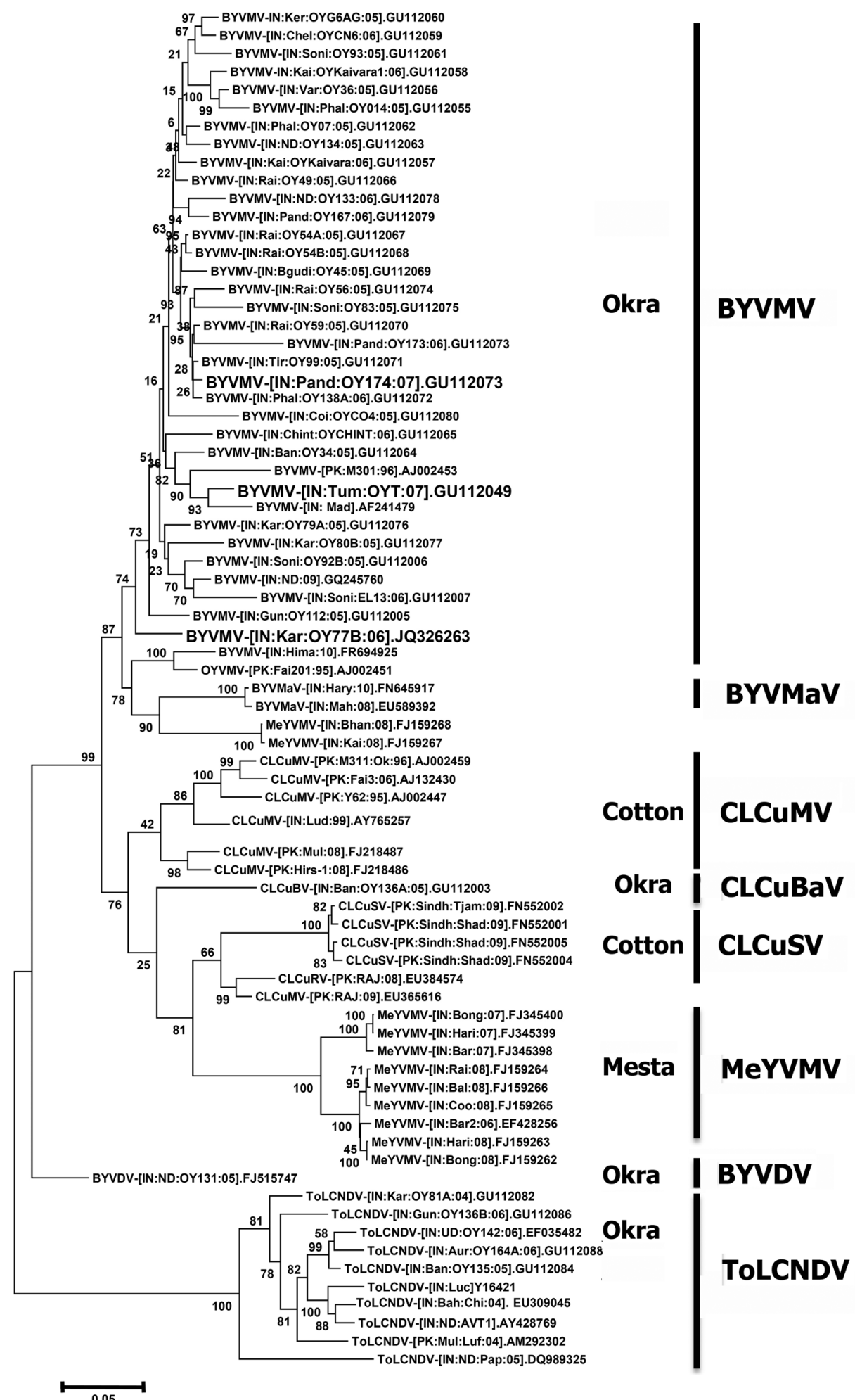




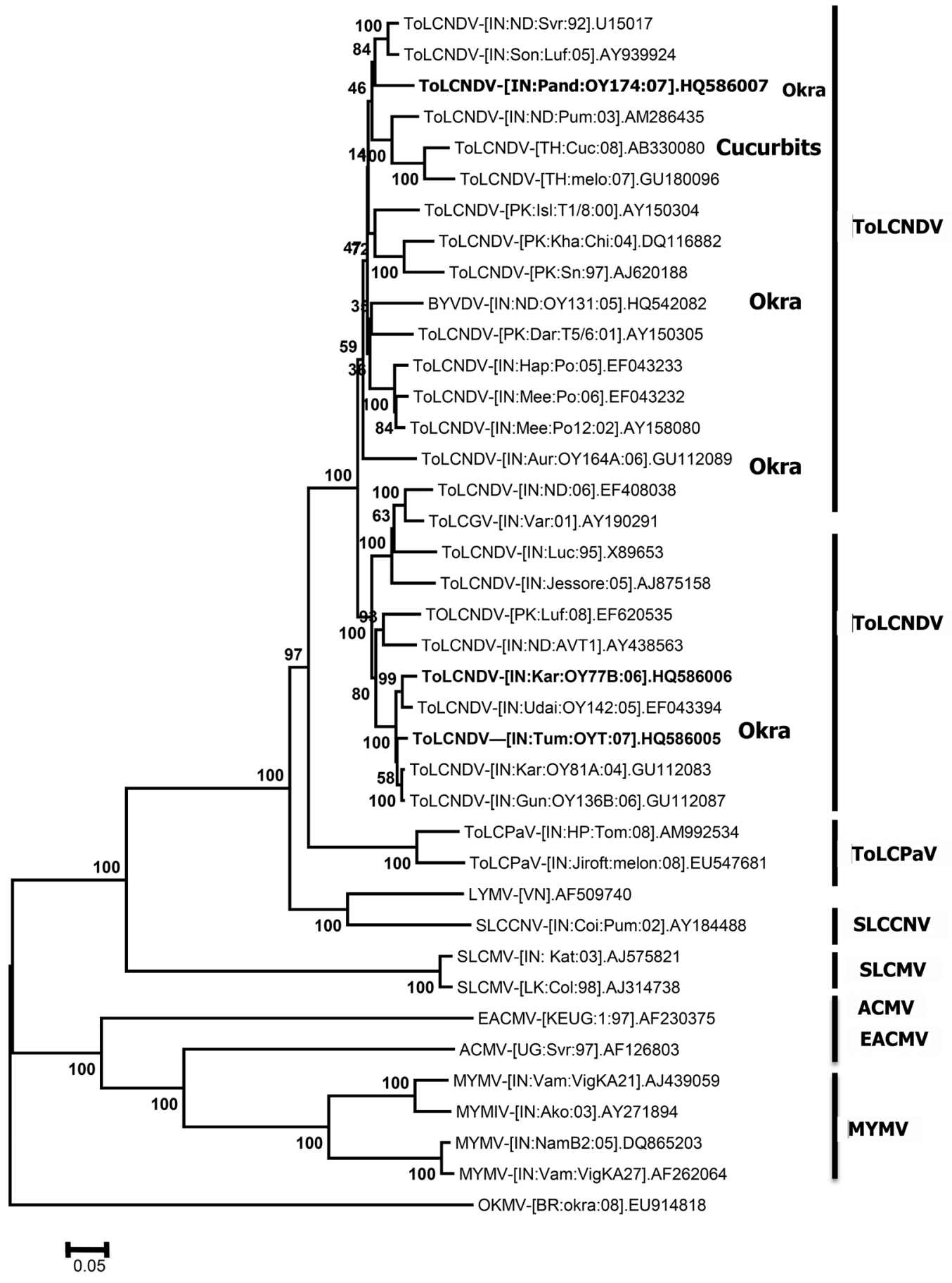

Fig. 1b

Dendograms were constructed using the Maximum parsimony method

(a) DNA-A sequence of begomoviruses (OY77B, OY-T\& OY174) and (b) DNA-B sequence of begomoviruses (OY77B, OY-T\& OY 174) associated with YVMD of okra from three distinct geographical regions in India. Branches corresponding to partitions reproduced in less than $50 \%$ bootstrap replicates are collapsed. The percentage of replicate trees in which the associated taxa clustered together in the bootstrap test (1,000 replicates) is shown below the branches. The Begomoviruses acronyms given are: bhendi yellow vein mosaic virus (BYVMV), cotton leaf curl Multan virus (CLCuMV), cotton leaf curl Rajasthan virus (CLCuRV), cotton leaf curl Bangalore virus (CLCuBV) cotton leaf curl Shahdadpur virus (CLCuSV), mesta yellow vein mosaic virus (MeYVMV), tomato leaf curl New Delhi virus (ToLCNDV), okra yellow vein mosaic virus (OYVMV), tomato leaf curl Palampur virus (ToLCPaV), squash leaf curl China virus (SLCCNV), tomato leaf curl Gujarat virus (ToLCGuV), Sri Lankan cassava mosaic virus (SLMCV), mungbean yellow mosaic virus (MYMV), mungbean yellow mosaic Indian virus (MYMIV), African cassava mosaic virus (ACMV), East African cassava mosaic virus (EACMV), okra mottle virus (OkMoV) and loofa yellow mosaic virus (LoYMV). 
it shared maximum identity with both BYMV and okra yellow vein mosaic virus (OYVMV), Rep (C1) region with cotton leaf curl Bangalore virus $(\mathrm{CLCuBaV})$ and $\mathrm{C} 5$ region with OYVMV (Table 1B). In the IR region, the sequence identities of begomoviruses were more than $94 \%$ with IRs of reported BYVMV isolates for which a full-length sequence is available in the databases (Table 1A). The length of IR of three isolates of begomovirus (OY77B, OY-T and OY174) ranged from 273-319 nts and is similar to those of other monopartite begomoviruses reported so far. Within the intergenic region they contain, incomplete direct repeats of an iteron sequence, GGTACC, present adjacent to the TATA box, which is presumably the Rep promoter (Heyraud et al., 1993; Arguello-Astorga et al., 1994; Hanley-Bowdoin et al., 1999) and share significant homology with iterons identified in DNA-A so far.

Genome organization and affinities of the DNA-B-like sequence

The complete DNA-B-like sequence of the virus isolates (OY-T, OY77B, and OY174) ranged from 2695-2698 nts in length and sequences are available in the NCBI database Acc. No. HQ586005, HQ586006 and HQ586007. So far, only one DNA-B-like sequence (HQ542082) corresponding to BYVDV (FJ515747) was reported. However, it was not associated with BYVMV or OYVMV. Therefore, apart from this the sequences of the DNA-B-like sequence of ToLCNDV, SLCCNV, ACMV and other begomoviruses were retrieved from the GenBank and used for the comparisons. Alignment of complete nucleotide sequences of DNA-B-like sequences with other sequences revealed that the two isolates OY77B and OY-T share 96.7-97.7\% nucleotide sequence identity with ToLCNDV (EF043394, GU112083) infecting okra and while OY174 had more than $90 \%$ nucleotide identity with ToLCNDV- Severe (U15017) infecting tomato (Table 3). This result is well supported by a phylogenetic analysis showing, the two okra isolates OY77B and OY-T are closely clustering with ToLCNDV-okra and OY174 clustering with ToLCNDV-Severe (U15017) (Fig. 1b). The IRs of these isolates (OY-T, OY778B, OY-174) share more than $90 \%$ identity with ToLCNDV isolates infecting different hosts (okra, luffa, tomato). The length of the IR ranged from 210-231 nts which was similar to ToLCNDV isolates available in the GenBank. Further, this region encompasses an absolutely conserved hairpin structure containing nonanucleotide sequence (TAATATTAC) that marks the origin of virion-strand DNA replication and repeated sequences known as "iterons" (GGAGTC) present adjacent to the TATA box in all three isolates (OY77B, OY174 and OY-T), that are recognition sequences for binding of the Rep promoter (Arguello-Astorga et al., 1994; Hanley-Bowdoin et al., 1999).

The isolates of the begomoviruses showed genome organization typical to other bipartite begomoviruses having two ORFs, one on the virion sense strand and the other on the complementary strand with the capacity to encode proteins of predicted molecular mass of $30 \mathrm{kDa}$ or more. When individually encoded proteins of three isolates (OY77B, OY174

Table 2. Features of the begomoviruses (OY77B, OY-T and OY174)) isolated from okra plant

\begin{tabular}{|c|c|c|c|c|c|c|c|c|c|c|c|c|}
\hline \multirow[b]{2}{*}{ 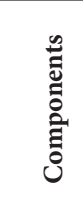 } & \multicolumn{4}{|c|}{ OY77B } & \multicolumn{4}{|c|}{ OY-T } & \multicolumn{4}{|c|}{ OY174 } \\
\hline & $\begin{array}{l}\text { Start } \\
\text { codon }\end{array}$ & $\begin{array}{l}\text { Stop } \\
\text { codon }\end{array}$ & $\begin{array}{c}\text { Predicted } \\
\text { size of } \\
\text { ORFs } \\
\text { (nt) }\end{array}$ & $\begin{array}{l}\text { Predicted size } \\
\text { of protein } \\
\text { (No. of amino } \\
\text { acids) and } \\
(\mathrm{Mw})\end{array}$ & $\begin{array}{l}\text { Start } \\
\text { codon }\end{array}$ & $\begin{array}{c}\text { Stop } \\
\text { codon }\end{array}$ & $\begin{array}{l}\text { Predicted } \\
\text { size of } \\
\text { ORFs } \\
\text { (nt) }\end{array}$ & $\begin{array}{l}\text { Predicted size } \\
\text { of protein } \\
\text { (No. of amino } \\
\text { acids) and } \\
(\mathrm{Mw})\end{array}$ & $\begin{array}{l}\text { Start } \\
\text { codon }\end{array}$ & $\begin{array}{l}\text { Stop } \\
\text { codon }\end{array}$ & $\begin{array}{l}\text { Predicted } \\
\text { size of } \\
\text { ORFs } \\
\text { (nt) }\end{array}$ & 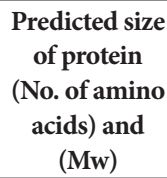 \\
\hline \multicolumn{13}{|c|}{ DNA-A } \\
\hline $\mathrm{CP}^{*}$ & 281 & 1051 & 771 & $\begin{array}{c}256^{* *} \\
(28.16 \mathrm{~K}) \#\end{array}$ & 281 & 1051 & 771 & 256 (28.16 K) & 327 & 1097 & 771 & $256(28.16 \mathrm{~K})$ \\
\hline V2 & 121 & 486 & 366 & $121(13.3 \mathrm{~K})$ & 121 & 486 & 366 & $121(13.3 \mathrm{~K})$ & 167 & 532 & 366 & $121(13.3 \mathrm{~K})$ \\
\hline Rep & 2588 & 1500 & 1089 & $362(39.82 \mathrm{~K})$ & 2588 & 1500 & 1089 & $362(39.82 \mathrm{~K})$ & 2637 & 1546 & 1092 & $363(40.30 \mathrm{~K})$ \\
\hline TrAP & 1603 & 1151 & 453 & $150(16.5 \mathrm{~K})$ & 1603 & 1151 & 453 & $150(16.5 \mathrm{~K})$ & 1649 & 1197 & 453 & $150(16.5 \mathrm{~K})$ \\
\hline REn & 1458 & 1054 & 405 & $134(15 \mathrm{~K})$ & 1458 & 1054 & 405 & $134(15 \mathrm{~K})$ & 1504 & 1100 & 405 & $134(15 \mathrm{~K})$ \\
\hline $\mathrm{C} 4$ & 2434 & 2132 & 303 & $100(11 \mathrm{~K})$ & 2434 & 2132 & 303 & $100(11 \mathrm{~K})$ & 2480 & 2178 & 303 & $100(11 \mathrm{~K})$ \\
\hline C5 & 985 & 629 & 357 & $118(12.98 \mathrm{~K})$ & 985 & 629 & 357 & $118(12.98 \mathrm{~K})$ & 1031 & 675 & 357 & $118(12.98 \mathrm{~K})$ \\
\hline \multicolumn{13}{|c|}{ DNA-B } \\
\hline $\begin{array}{l}\text { NSP } \\
\text { (BV1) }\end{array}$ & 442 & 1248 & 807 & $268(30 \mathrm{~K})$ & 446 & 1252 & 807 & $268(30 \mathrm{~K})$ & 443 & 1249 & 807 & $268(30 \mathrm{~K})$ \\
\hline $\begin{array}{l}\text { MP } \\
(\mathrm{BC} 1)\end{array}$ & 2150 & 1305 & 846 & $281(31 \mathrm{~K})$ & 2154 & 1309 & 846 & $281(31 \mathrm{~K})$ & 2152 & 1307 & 846 & $281(31 \mathrm{~K})$ \\
\hline
\end{tabular}

${ }^{\star}$ Genes are indicated as coat protein $(\mathrm{CP})$, replication-associated protein (Rep), transcriptional activator protein (TrAP), and replication enhancer (REn). The products encoded by ORFs V2, C4 and C5 have yet to be named. ${ }^{* *}$ Total number of amino acids encoded by gene. \#Predicted molecular mass. 
Table 3. Percentage of identity of nucleotide sequences and amino acid sequences of different proteins encoded by DNA-B-like sequence of ToLCDNV isolates (OY77B, OY-T and OY174) with other selected begomoviruses

\begin{tabular}{|c|c|c|c|c|c|c|c|c|c|c|c|c|c|}
\hline \multirow{2}{*}{ Begomoviruses } & \multirow{2}{*}{ Acc. No. } & \multicolumn{4}{|c|}{ OY77B } & \multicolumn{4}{|c|}{ OY-T } & \multicolumn{4}{|c|}{ OY174 } \\
\hline & & Genome $^{a}$ & $\mathbf{I R}^{\mathrm{a}}$ & BV1 $^{\text {b }}$ & BC1 $^{\text {b }}$ & Genome $^{a}$ & $\mathbf{I R}^{\mathrm{a}}$ & BV1 $^{\text {b }}$ & $\mathrm{BCl}^{\mathrm{b}}$ & Genome $^{a}$ & $\mathbf{I R}^{\mathrm{a}}$ & BV1 $^{\text {b }}$ & $\mathrm{BC1}^{\mathrm{b}}$ \\
\hline ToLCPaV-[Tomato] & AM992534 & 67.3 & 48.1 & 77.6 & 88.6 & 67.7 & 54.1 & 79.1 & 88.9 & 68.3 & 49.7 & 78.3 & 89.6 \\
\hline ToLCKeV-[Jiroft] & EU547681 & 66.9 & 31.8 & 87.5 & 88.6 & 67.0 & 36.7 & 87.9 & 88.2 & 67.2 & 32.8 & 85.7 & 87.5 \\
\hline ToLCNDV-[chilli] & DQ116882 & 82.2 & 85.8 & 92.1 & 95.0 & 83.0 & 82.2 & 93.6 & 94.6 & 85.3 & 91.9 & 94.4 & 93.9 \\
\hline $\begin{array}{l}\text { ToLCNDV- } \\
\text { [Solanum] }\end{array}$ & AJ620188 & 81.1 & 86.4 & 70.5 & 93.5 & 81.9 & 81.9 & 72.7 & 93.9 & 85.1 & 92.5 & 74.6 & 92.5 \\
\hline $\begin{array}{l}\text { ToLCNDV- } \\
\text { Okra[OY142] }\end{array}$ & EF043394 & $\underline{96.7}$ & 82.5 & $\underline{97.0}$ & 98.5 & 97.0 & 88.7 & 94.7 & 98.9 & 85.1 & 74.8 & 89.1 & 91.8 \\
\hline $\begin{array}{l}\text { ToLCNDV- } \\
\text { Okra[OY81A] }\end{array}$ & GU112083 & 95.4 & 80.8 & 96.2 & $\underline{99.2}$ & $\underline{97.7}$ & $\underline{90.3}$ & $\underline{98.5}$ & $\underline{99.6}$ & 86.2 & 75.7 & 92.9 & 92.5 \\
\hline $\begin{array}{l}\text { ToLCNDV- } \\
\text { Okra[OY136B] }\end{array}$ & GU112087 & 95.7 & 81.3 & 96.6 & $\underline{99.2}$ & $\underline{97.6}$ & 89.9 & 98.1 & $\underline{99.6}$ & 86.1 & 75.3 & 92.5 & 92.5 \\
\hline ToLCNDV-[Luffa] & EF620535 & 92.9 & $\underline{93.5}$ & 87.5 & 88.0 & 90.2 & 81.9 & 87.9 & 87.6 & 84.4 & 85.3 & 85.7 & 84.5 \\
\hline ToLCNDV-[AVT1] & AY438563 & 89.6 & 78.4 & 91.7 & 98.2 & 89.3 & 84.7 & 92.1 & 97.8 & 85.2 & 74.8 & 91.0 & 91.8 \\
\hline ToLCNDV-[Tomato] & EF408038 & 86.3 & 85.7 & 82.5 & 96.7 & 86.6 & 81.8 & 82.5 & 97.1 & 82.7 & 87.7 & 81.1 & 91.4 \\
\hline ToLCGV-[Varanasi] & AY190291 & 86.8 & 86.2 & 88.2 & 97.5 & 87.3 & 80.5 & 89.3 & 97.8 & 83.6 & 88.2 & 86.8 & 92.1 \\
\hline $\begin{array}{l}\text { ToLCNDV- } \\
\text { Severe[Jessor] }\end{array}$ & AJ875158 & 86.2 & 71.9 & 91.7 & 97.1 & 86.5 & 79.9 & 92.1 & 97.5 & 82.7 & 73.2 & 89.5 & 92.5 \\
\hline $\begin{array}{l}\text { ToLCNDV- } \\
\text { [Lucknow] }\end{array}$ & X89653 & 84.6 & 73.8 & 81.9 & 95.3 & 84.6 & 79.6 & 82.2 & 95.7 & 81.7 & 75.0 & 81.2 & 91.8 \\
\hline $\begin{array}{l}\text { ToLCNDV- } \\
\text { Okra[164A] }\end{array}$ & GU112089 & 88.6 & 82.5 & 86.9 & 93.9 & 90.4 & 88.7 & 89.1 & 93.5 & 85.9 & 74.8 & 88.8 & 93.5 \\
\hline ToLCNDV-[Severe] & U15017 & 85.9 & 88.6 & 91.4 & 86.6 & 86.9 & 84.8 & 93.6 & 86.9 & $\underline{91.7}$ & $\underline{94.3}$ & $\underline{96.2}$ & 87.3 \\
\hline ToLCNDV-[Luffa] & AY939924 & 83.8 & 57.8 & 85.9 & 93.2 & 84.9 & 62.1 & 88.0 & 93.5 & 89.8 & 61.1 & 90.4 & 95.3 \\
\hline $\begin{array}{l}\text { ToLCNDV- } \\
\text { [cucumber] }\end{array}$ & AB330080 & 80.8 & 66.4 & 83.9 & 93.9 & 81.5 & 73.9 & 85.0 & 93.5 & 84.5 & 68.7 & 86.5 & 94.6 \\
\hline ToLCNDV-[OM] & GU180096 & 79.6 & 66.4 & 85.8 & 92.8 & 80.6 & 73.1 & 87.6 & 92.5 & 83.0 & 67.9 & 88.4 & 93.2 \\
\hline $\begin{array}{l}\text { ToLCNDV- } \\
\text { [Pumpkin] }\end{array}$ & AM286435 & 84.2 & 85.8 & 89.9 & 95.7 & 84.8 & 81.8 & 91.0 & 95.3 & 89.1 & 92.9 & 92.5 & $\underline{96.0}$ \\
\hline ToLCNDV-[Potato] & EF043232 & 85.4 & 87.7 & 90.6 & 92.8 & 86.0 & 83.5 & 91.7 & 92.5 & 88.1 & 91.5 & 93.6 & 93.5 \\
\hline ToLCNDV-[Potato] & AY158080 & 86.0 & 86.7 & 66.4 & 93.2 & 86.7 & 83.9 & 67.5 & 92.8 & 88.8 & 91.5 & 69.0 & 93.9 \\
\hline ToLCNDV-[Potato] & EF043233 & 85.5 & 77.3 & 86.0 & 93.9 & 86.3 & 87.9 & 87.1 & 93.5 & 88.2 & 81.5 & 896 & 94.6 \\
\hline ToLCNDV-[T5/6] & AY150305 & 83.2 & 84.9 & 91.4 & 93.2 & 84.1 & 79.2 & 93.6 & 92.8 & 87.2 & 89.1 & 95.5 & 94.3 \\
\hline ToLCNDV-[PkT1/8] & AY150304 & 83.4 & 55.4 & 88.8 & 95.0 & 84.4 & 56.3 & 89.9 & 94.6 & 86.3 & 58.8 & 89.9 & 95.0 \\
\hline LoYMV-[VN] & AF509740 & 64.2 & 56.0 & 73.8 & 84.6 & 64.9 & 58.9 & 74.2 & 85.0 & 64.2 & 57.4 & 73.1 & 84.3 \\
\hline SLCCNV.[Pumpkin] & AY184488 & 61.8 & 42.2 & 71.2 & 88.2 & 62.0 & 39.6 & 71.6 & 88.6 & 62.1 & 41.6 & 72.3 & 89.3 \\
\hline SLCMV-[Ker4] & AJ575821 & 42.1 & 32.4 & 37.5 & 58.3 & 42.4 & 35.7 & 37.5 & 58.3 & 42.2 & 35.3 & 37.1 & 57.3 \\
\hline SLCMV.[Colombo] & AJ314738 & 42.4 & 33.7 & 31.6 & 58.3 & 42.7 & 36.6 & 31.6 & 58.3 & 42.5 & 37.1 & 31.6 & 57.6 \\
\hline MYMV-[Vigna] & AJ439059 & 38.9 & 26.9 & 25.6 & 40.0 & 38.5 & 27.4 & 25.2 & 40.0 & 37.4 & 27.3 & 24.9 & 38.4 \\
\hline MYMIV.[Akola] & AY271894 & 38.5 & 18.2 & 25.2 & 39.7 & 38.4 & 20.6 & 25.2 & 39.7 & 37.3 & 18.9 & 24.9 & 38.7 \\
\hline MYMV-Namakkal & DQ865203 & 38.8 & 21.9 & 24.1 & 40.7 & 38.3 & 24.1 & 24.1 & 40.7 & 37.6 & 23.9 & 24.1 & 39.7 \\
\hline $\begin{array}{l}\text { MYMV- } \\
\text { Vigna[KA27] }\end{array}$ & AF262064 & 39.0 & 21.6 & 23.7 & 25.6 & 38.5 & 24.9 & 23.7 & 25.6 & 37.7 & 21.9 & 23.7 & 25.2 \\
\hline ACMV-[Ug/Svr] & AF126803 & 39.4 & 34.4 & 24.5 & 39.6 & 39.2 & 31.8 & 24.9 & 39.6 & 39.0 & 33.1 & 24.1 & 37.2 \\
\hline EACMV-[Ug1] & AF230375 & 36.1 & 29.8 & 25.6 & 39.7 & 36.2 & 33.0 & 25.6 & 39.7 & 35.8 & 29.5 & 25.2 & 39.4 \\
\hline OkMoV-[BR:okra] & EU914818 & 37.0 & 29.0 & 27.0 & 40.6 & 37.0 & 31.0 & 27.7 & 40.6 & 36.8 & 29.3 & 27.7 & 40.9 \\
\hline
\end{tabular}

aNucleotide identity; ${ }^{\mathrm{b}} \mathrm{Amino}$ acid identity. BV1 = nuclear shuttle protein gene, $\mathrm{BC} 1=$ movement protein gene. \#The species are indicated as, tomato leaf curl New Delhi virus (ToLCNDV), tomato leaf curl Palampur virus (ToLCPaV), squash leaf curl China virus (SLCCNV), tomato leaf curl Gujarat virus (ToLCGuV), Sri Lankan cassava mosaic virus (SLMCV), mungbean yellow mosaic virus (MYMV), mungbean yellow mosaic Indian virus (MYMIV), African cassava mosaic virus (ACMV), East African cassava mosaic virus (EACMV), okra mottle virus (OkMoV) and loofa yellow mosaic virus (LoYMV). For each column the highest nucleotide and amino acid identity value is underlined. 
and OY-T) were compared, the highest amino acid sequence similarities of the predicted gene products for nuclear shuttle protein (NSP) (BV1) and movement protein (BC1) of OY-T and OY77B were similar to ToLCNDV-okra. While, OY174 shared maximum identity with ToLCNDV-Severe (U15017) and ToLCNDV-pumpkin (AM286435) in BV1 and BC1 regions, respectively (Table 3 ).

\section{Detection of recombination}

In the present study, we characterized recombination events in okra begomoviruses. The sequences of different begomoviruses infecting malvaceous, solanaceous, cucurbits, cassava and legume crops were retrieved from the database. Initially the neighbor-net analysis was carried out using Splits-Tree (version 4.11.3). It revealed clear substantiation of phylogenetic conflicts within the analyzed sequences; meaning that every sequence represented within the tree was implicated as a potential recipient of horizontally acquired sequences at some time in its evolutionary past. Based on these criteria, we further analyzed sequences in recombination detection program (RDP3) to know the exact places of recombination in the genome of the begomoviruses. The recombination breakpoint analysis provided strong evidence for the presence of recombination in all three isolates (OY77B, OY174 and OY-T) and it is summarized in the Table 4. The major recombination events are presented in Fig. 2. The analysis of DNA-A component showed evidence for recombination in all three isolates (OY77B, OY 174 and OY-T) with most of the sequences originating from both monoparite and bipartite begomoviruses in OY77B (BYVMV, CLCuMuV, MeYVMV and ToLCNDV), OY174 (BYVMV and ToLCNDV) and OY-T (BYVMV BYVDV and ToLCNDV) (Table 4). Similar analysis was carried out for DNA-B component of ToLCNDV associated with okra samples. The detection of many breakpoints showed larger fragments of putative recombinant origin. Further, the evidence clearly indicates these segments are derived from the recombination among the ToLCNDV infecting different host plants. The exchanged sequences in IR region and ORFs of MP and NSP gene of DNA-B component of okra begomovirus isolates (OY77B, OY174 and OY-T) and begomovirus species provide further evidence for recombination in begomoviruses.

\section{Discussion}

The majority of begomoviruses characterized from okra and closely related crops across the globe are monopartite and are associated with betasatellites and alphasatellites (Briddon et al., 2001, 2003; Jose and Usha 2003; Saunders et al., 2000) with the exception of weeds namely Sida and
Malvestrum (Graham et al., 2010; Zepeda et al., 2007), and a recent report in okra (Venkataravanappa et al., 2012a), which are infected with new bipartite begomoviruses. The sampling data presented here, after confirmation with the dot blot and PCR analysis, suggests that although the monopartite begomovirus complex is predominant in okra across India, there is good number of samples (43 out of 173) with bipartite genome (DNA-A and DNA-B) likesequences, where we were unable to confirm the presence of betasatellite.

Two lines of evidence support our argument that, these samples doesn't associate with the betasatellites. Firstly, we used universal primers for amplification of betasatellites that have been successfully used for amplification of betasatellites originating from diverse locations. Secondly, those samples which are negative to the betasatellite were positive for ToLCNDV probe designed for DNA-B-like sequence isolated from the okra suggesting the increasing trend of bipartite begomoviruses infecting okra in the Indian subcontinent. Overall, evidence at present suggests that BYVMV has adapted co-infection either with BYVB or with DNA-B-like sequence of ToLCNDV.

Further, both betasatellite and DNA-B-like sequence are involved in systemic virus movement of ToLCNDV in tomato (Sivalingam et al., 2010) and it seems that the begomovirus has adapted for use of either of these to infect okra. The wide geographical areas from where these samples were obtained suggest that there may be several incidences of co-infection of BYVMV with DNA-B-like sequence of ToLCNDV. Several strains of DNA-B-like sequences of ToLCNDV are available in the database and at least two distinct strains were found in okra in this study. We did not find evidence for geographical segregation of DNA-B-like sequence in okra. Future study may help to see if distinct strains are geographically isolated. The absence of betasatellite in samples, where DNA-B-like sequence was positive has several implications on the role of DNA components involved in induction of disease symptoms. Although, there are variations in symptom severity in okra samples used in this study. We were unable to predict the association of betasatellite or DNA-B-like sequence by symptoms alone. Therefore, the symptom determinant involved in induction of yellow vein symptoms is likely to be encoded by begomovirus (Jose and Usha, 2003). Previously it was shown, that inoculation of chilli leaf curl virus (ChiLCuV) alone resulted in mild symptoms in tomato and chillies, however, the presence of both, betasatellite and DNA-B, results in severe leaf curl symptoms (Shafiq et al., 2010; Akhtar et al., 2009). The emergence of begomoviruses associated with the multiple components (Shafiq et al., 2010; Akhtar et al., 2009) will add to further complexity of the begomovirus evolution in the sub-continent. Interaction of these multiple components in disease development 


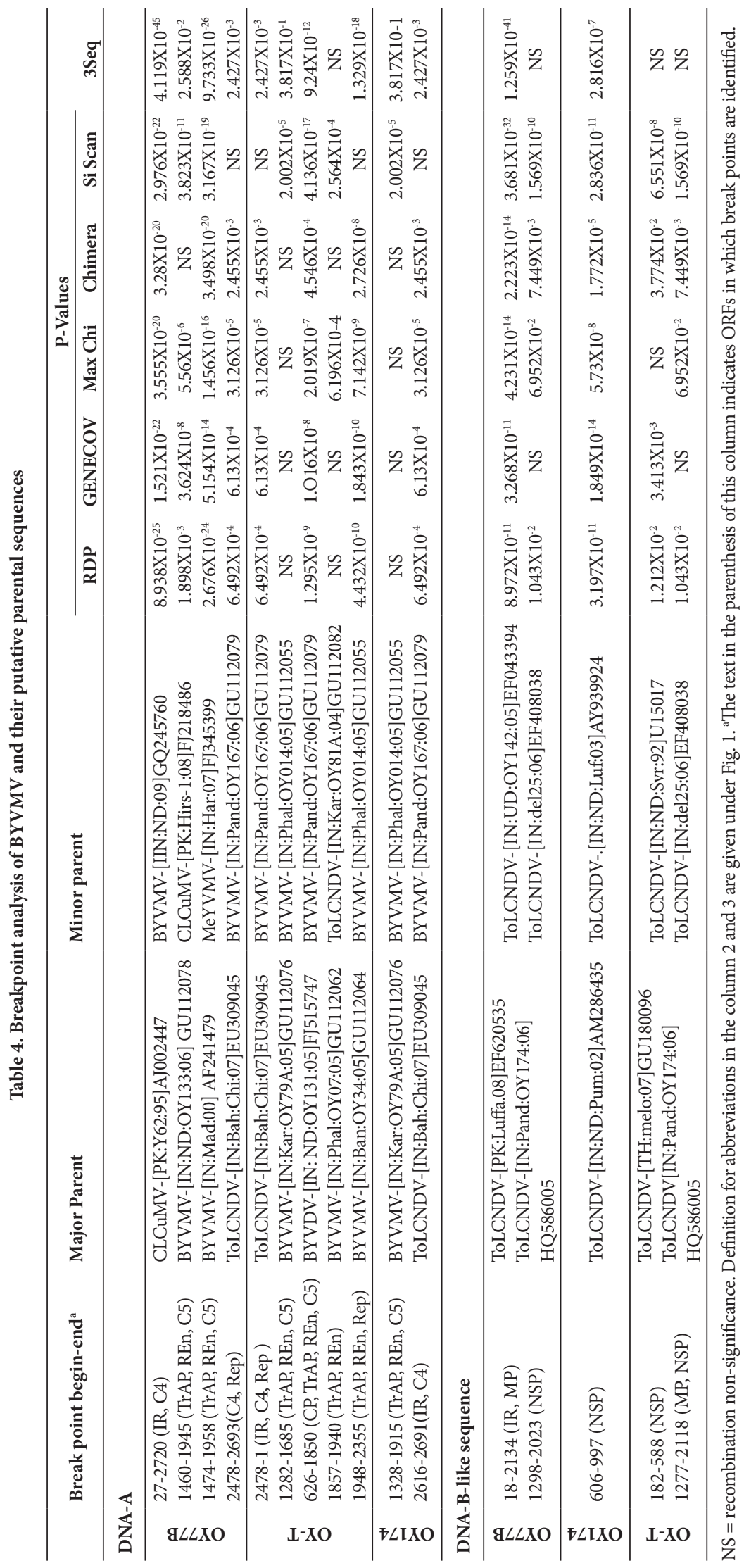


needs to be further explored for better understanding of begomovirus evolution.

Interestingly, ToLCNDV a bipartite begomovirus is an economically important pathogen found to be associated with various cultivated and non-cultivated crop plants in India, Pakistan, Thailand and Bangladesh (Fauquet et al., 2008). The virus was reported in tomato two decades back from India (Padidam et al., 1995; Srivastava et al., 1995) and subsequently from many crops and weeds such as, chili (Hussain et al., 2004), cucurbits (Ito et al., 2008), papaya (Raj et al., 2008; Krishna Reddy et al., 2010), bitter gourd (Tahir et al., 2005; Tiwari et al., 2010), eggplant (Pratap et al., 2011), and Oriental melon (Chang et al., 2010). Therefore, virus has

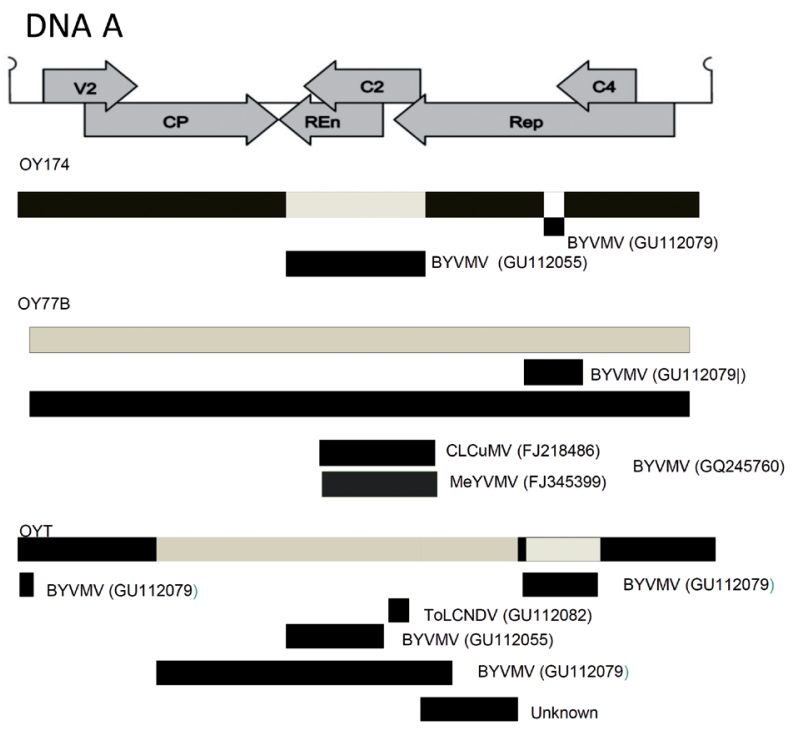

DNA B
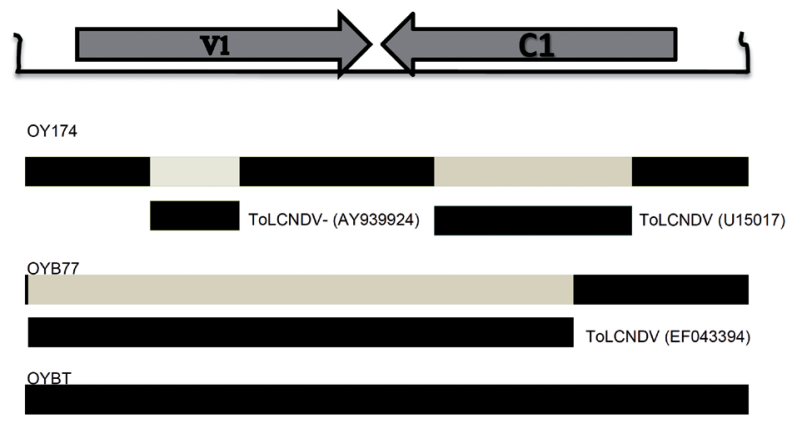

Fig. 2

Analysis of recombination of DNA-A and DNA-B of virus isolates (OY174, OYB77B and OY-T) from okra

The Begomoviruses acronyms given are: bhendi yellow vein mosaic virus (BYVMV), cotton leaf curl Multan virus (CLCuMV), mesta yellow vein mosaic virus (MeYVMV), and tomato leaf curl New Delhi virus (ToLCNDV). Sequence of indeterminate origin is indicated as "unknown". The bars below the isolate name indicate their genome and the boxes below this with virus acronyms indicate the approximate position at which recombination has occurred in the genome of virus isolates. flexibility in its interaction with other begomovirus components that may help begomoviruses to expand host range (Shafiq et al., 2010). The association of different species of monopartite and bipartite begomoviruses exist across India and many monopartite begomoviruses with betasatellite molecules are already known to be prevalent in southern India (Chowda Reddy et al., 2005).

The recent studies showed that ToLCNDV, DNA-B-like sequence captured by chilli leaf curl monoparite begomovirus under field conditions resulted in causing severe symptoms on chilli (Khan et al., 2006) and also it was experimentally proved by agroinoculation (Shafiq et al., 2010). Further, tomato leaf curl Gujarat virus captured the DNA-B-like-sequence of ToLCNDV, resulting in a virus capable of inducing more severe disease symptoms on tomato (Chakraborty et al., 2008; Briddon et al., 2010). Based on available evidence, the enhanced virulence in new viruses to infect other crop plants can be attributed to selective advantage they have in component capture during mixed infection, probably in weed hosts.

Geminiviruses replicate via rolling circle mechanism in which high affinity binding of viral Rep to the cognate origin of DNA, which recognizes repeated sequences, known as iterons, in the common region immediately upstream of a hairpin structure that contains the ubiquitous (for geminiviruses) nonanucleotide sequence (TAATATTAC) (Hanley-Bowdoin et al., 1999). Rep then initiates replication by nicking in the nonanucleotide sequence. The DNA-A- and DNA-B-like sequence of bipartite begomoviruses has the same iteron sequences, thereby ensuring that the DNA-Aencoded Rep may initiate replication of both components; maintaining the integrity of the split genome (Shafiq et al., 2010).

Recombination has been described as one of the most frequent diversification mechanisms (Padidam et al., 1999; Monci et al., 2002; Lozano et al., 2009) especially in geminivirus populations where it strongly contributes to its genetic diversification (Sanz et al., 2000). In begomoviruses, recombination is so frequent that it can occur at the strain (Fondong et al., 2000) or species levels (Martin et al., 2001; Saunders et al., 2002). In present study, we sought to characterize recombination between okra begomoviruses and begomoviruses infecting plants belonging to different families like malvaceous plants, solanaceous plants, cucurbits, cassava and legume crops, using a different approach to those used previously to study the recombination in begomoviruses (Prasanna and Rai, 2007; Kumari et al., 2010). The analysis indicates only inter-specific recombination in isolates (OY-T OY77B and OY174) which have a chimeric genome that arose from recombination events between begomoviruses infecting okra (BYVMV), chilli, mesta and cotton. Similarly, for DNA-B-like sequence, most of the fragments are probably descended through a recombina- 
tion from ToLCNDV infecting okra, tomato and luffa. The aminoacid comparison data (identity ranges for $\mathrm{V} 2$ and $\mathrm{C} 4$ of some viruses are surprisingly broad) further provide some evidence for recombination in these isolates. These findings are consistent with several other previous studies and support the idea that recombination among begomovirus strains or species is an important driving force in the evolution of new viruses (Kon et al., 2006; Padidam et al., 1999).

We have recently reported the diversity of betasatellites which revealed the variability of the begomovirus complexes associated with yellow vein mosaic and enation leaf curl disease of okra in India (Venkataravanappa et al., 2011). Here we have shown the association of DNA-B in okra samples collected from diverse locations. The data presented here and our previous studies therefore suggest that complex of begomovirus components are found in okra. These findings may have important implications on efforts aimed at breeding resistant cultivars of okra for cultivation across the Indian subcontinent.

Acknowledgements. The research was supported by ICAR NETWORK project on development of diagnostics to emerging plant viruses, Indian Council of Agricultural Research, Government of India, New Delhi. We are thankful to Dr. Shahid Mansoor, National Institute for Biotechnology and Genetic Engineering (NIBGE), Faisalabad, Pakistan for his suggestions in manuscript preparation.

\section{References}

Akhter J, Qazi, Saeed M, Mansoor S (2009): A severe leaf curl disease on chilies in Pakistan is associated with multiple begomovirus components. Plant Dis. 93, 962-962. http:// dx.doi.org/10.1094/PDIS-93-9-0962B

Arguello-Astorga GR, Guevara-González LR, Herrera-Estrella LR, Rivera-Bustamante RF (1994): Geminivirus replication origins have a group-specific organization of iterative elements: a model for replication. Virology 203, 90-100. http://dx.doi.org/10.1006/viro.1994.1458

Briddon RW, Bull SE, Mansoor S, Amin I, Markham PG (2002): Universal primers for the PCR-mediated amplification of DNA beta: A molecule associated with some monopartite begomoviruses. Mol. Biotech. 20, 315-318. http://dx.doi. org/10.1385/MB:20:3:315

Briddon RW, Bull SE, Amin I, Idris AM, Mansoor S, Bedford ID, Dhawan P, Rishi N, Siwatch SS, Abdel-Salam AM, Brown JK, Zafar Y, Markham PG (2003): Diversity of DNA- $\beta$, a satellite molecule associated with some monopartite begomoviruses. Virology 312, 106-121. http://dx.doi. org/10.1016/S0042-6822(03)00200-9

Briddon RW, Mansoor S, Bedford ID, Pinner MS, Saunders K, Stanley J, Zafar Y, Malik K, Markham PG (2001): Identification of DNA components required for induction of cotton leaf curl disease. Virology 285, 234-243. http://dx.doi.org/10.1006/ viro.2001.0949

Briddon RW, Patil BL, Basavaraj B, Nawaz-ul-Rehman MS, Fauquet CM (2010): Distinct evolutionary histories of the DNA-A and DNA-B components of bipartite begomoviruses. B.M. C. Evol. Biology 10, 97. http://dx.doi.org/10.1186/14712148-10-97

Chakraborty S, Vanitharani R, Chattopadhyay B, Fauquet CM (2008): Supervirulent pseudorecombination and asymmetric synergism between genomic components of two distinct species of begomovirus associated with severe tomato leaf curl disease in India. J. Gen. Virol. 89, 818-828. http://dx.doi.org/10.1099/vir.0.82873-0

Chang HH, Ku HM, Tsai WS, Chien RC, Jan FJ (2010): Identification and characterization of a mechanical transmissible begomovirus causing leaf curl on oriental melon. Eur. J. Plant Pathol. 127, 219-228. http://dx.doi.org/10.1007/ s10658-010-9586-0

Chowda Reddy RV, Colvin J, Muniyappa V, Seal S (2005): Diversity and distribution of begomoviruses infecting tomato in India. Arch. Virol. 150, 845-867. http://dx.doi.org/10.1007/ s00705-004-0486-5

Dietzgen RG (1997): Detection of groundnut viruses by molecular hybridization with non-radioactive DNA probe. Australia: Queensland Agricultural Biotechnology Centre.

Doyle JJ, Doyle JJ (1990): Isolation of plant DNA from fresh tissue. Focus 12, 13-15.

Fauquet CM, Briddon RW, Brown JK, Moriones E, Stanley J, Zerbini M, Zhou X (2008): Geminivirus strain demarcation and nomenclature. Arch. Virol. 153, 783-821. http://dx.doi. org/10.1007/s00705-008-0037-6

Fondong VN, Pita JS, Rey MEC, Dekochko A, Beachy RN, Fauquet CM (2000): Evidence of synergism between African cassava mosaic virus and a new double recombinant geminivirus infecting cassava in Cameroon. J. Gen. Virol. 81, 287-297.

Graham AP, Martin DP, Roye ME (2010): Molecular characterization and phylogeny of two begomoviruses infecting Malvastrum americanum in Jamaica: evidence of the contribution of inter-species recombination to the evolution of malvaceous weed-associated begomoviruses from the Northern Caribbean. Virus Genes 40, 256-266. http:// dx.doi.org/10.1007/s11262-009-0430-6

Hall TA (1999): BioEdit: a user-friendly biological sequence alignment editor and analysis program for Windows 95/98/ NT. Nucleic Acids 41, 95-98.

Hanley-Bowdoin L, Settlage SB, Orozco BM, Nagar S, Robertson D (1999): Geminiviruses: Models for plant DNA replication, transcription, and cell cycle regulation. Cri. Rev. Pl. Sci. 18, 71-106. http://dx.doi. org/10.1080/07352689991309162

Harrison B, Robinson D (1999): Natural genomic and antigenic variation in whitefly-transmitted geminiviruses (Begomoviruses). Annu. Rev. Phytopathol. 37, 369-398. http:// dx.doi.org/10.1146/annurev.phyto.37.1.369

Heyraud F, Matzeit V, Kammann M, Schafer S, Schell J, Gronenborn B (1993): Identification of the initiation sequence 
for viral-strand DNA synthesis of wheat dwarf virus. Eur. Mol. Biol. J. 12, 4445-4452.

Huson DH, Bryant D (2006): Application of phylogenetic networks in evolutionary studies. Mol. Biol. Evol. 23, 254-267. http://dx.doi.org/10.1093/molbev/msj030

Hussain M, Mansoor S, Iram S, Zafar Y, Briddon RW (2004): First report of Tomato leaf curl New Delhi virus affecting chilli pepper in Pakistan. Plant Pathol. 53, 794. http://dx.doi. org/10.1111/j.1365-3059.2004.01073.x

Ito T, Sharma P, Kittipakorn K and Ikegami M (2008): Complete nucleotide sequence of a new isolate of Tomato leaf curl New Delhi virus infecting cucumber, bottle gourd and muskmelon in Thailand. Arch. Virol. 153, 611-613. http:// dx.doi.org/10.1007/s00705-007-0029-y

Jeske H, Lutgemeier M, Preiss W (2001): DNA forms indicate rolling circle and recombination-dependent replication of Abutilon mosaic virus. Eur. Mol. Biol. J. 20, 6158-6167. http://dx.doi.org/10.1093/emboj/20.21.6158

Jose J, Usha R (2003): Bhendi yellow vein mosaic disease in India is caused by association of a DNA $b$ satellite with a begomovirus. Virology 305, 310-317. http://dx.doi.org/10.1006/ viro.2002.1768

Khan MS, Raj SK, Singh R (2006): First report of tomato leaf curl New Delhi virus infecting chilli in India. Plant Pathol. 55, 289-289. http://dx.doi.org/10.1111/j.1365-3059 $.2006 .01324 . \mathrm{x}$

Kon T, Kuwabara K, Hidayat SH, Ikegami M (2006): A begomovirus associated with ageratum yellow vein disease in Indonesia: evidence for natural recombination between tomato leaf curl Java virus and Ageratum yellow vein virus-[Java]. Arch. Virol. 152, 1147-1157. http://dx.doi.org/10.1007/ s00705-006-0928-3

Krishna Reddy M, Venkataravanappa V, Madhuvanthi B, Jalali S (2010): Molecular characterization of begomoviruses associated with papaya leaf curl disease in India. Acta Hort. 851, 465-472.

Kulkarni GS (1924): Mosaic and other related diseases of crops in the Bombay presidency. Poona Agricultural College Magazine 16, 6-12.

Kumari P, Singh AK, Chattopadhyay B, Chakraborty S (2010): Molecular characterization of a new species of begomovirus and betasatellite causing leaf curl disease of tomato in India. Virus Res. 152, 19-29. http://dx.doi.org/10.1016/j. virusres.2010.05.015

Lazarowitz SG (1992): Geminiviruses: genome structure and gene function. Cri. Rev. Pl. Sci. 11, 327-349. http://dx.doi. org/10.1080/07352689209382350

Lefeuvre P, Martin DP, Hoareau M, Naze F, Delatte H, Thierry M, Varsani A, Becker N, Reynaud B, Lett JM (2007): Begomovirus 'melting pot' in the southwest Indian Ocean islands: molecular diversity and evolution through recombination. J. Gen. Virol. 88, 3458-3468. http://dx.doi. org/10.1099/vir.0.83252-0

Lozano G, Helena P, Trenado, Rodrigo A, Valverde, Navas-Castillo $J$ (2009): Novel begomovirus species of recombinant nature in sweet potato (Ipomoea batatas) and Ipomoea indica: taxonomic and phylogenetic implications. J. Gen. Virol. 90, 2550-2562. http://dx.doi.org/10.1099/vir.0.012542-0
Martin DP, Lemey P, Lott M, Vincent M, Posada D, Lefeuvre P (2010): RDP3: a flexible and fast computer program for analyzing recombination. Bioinformatics $26,2462-2463$. http://dx.doi.org/10.1093/bioinformatics/btq467

Martin DP, Willment JA, Billharz R, Velders R, Odhiambo B, Njuguna J, James D, Rybicki EP (2001): Sequence diversity and virulence in Zea mays of maize streak virus isolates. Virology 288, 247-255. http://dx.doi.org/10.1006/ viro.2001.1075

Monci F, Sanchez-Campos S, Navas-Castillo J, Moriones E (2002): A natural recombinant between the geminiviruses tomato yellow leaf curl Sardinia virus and tomato yellow leaf curl virus exhibits a novel pathogenic phenotype and is becoming prevalent in Spanish populations. Virology 303, 317-326. http://dx.doi.org/10.1006/viro.2002.1633

Morales FJ, Anderson PK (2001): The emergence and dissemination of whitefly transmitted viruses in Latin America. Arch. Virol. 146, 415-441. http://dx.doi.org/10.1007/ $\underline{\mathrm{s} 007050170153}$

Padidam M, Beachy RN, Fauquet CM (1995): Tomato leaf curl geminivirus from India has a bipartite genome and coat protein is not essential for infectivity. J. Gen. Virol. 76, 25-35. http://dx.doi.org/10.1099/0022-1317-76-1-25

Padidam M, Sawyer SY, Fauquet CM (1999): Possible emergence of new geminiviruses by frequent recombination. Virology 265, 218-225. http://dx.doi.org/10.1006/viro.1999.0056

Polston JE, Anderson PL (1997): The emergence of whitefly transmitted geminiviruses in tomato in the Western Hemisphere. Plant Dis. 81, 1358-1369. http://dx.doi. org/10.1094/PDIS.1997.81.12.1358

Prasanna HC, Rai M (2007): Detection and frequency of recombination in tomato-infecting begomoviruses of South and Southeast Asia. Virol. J. 4, 111. http://dx.doi. org/10.1186/1743-422X-4-111

Pratap D, Kashikar AR, Mukherjee SK (2011): Molecular characterization and infectivity of a tomato leaf curl New Delhi virus variant associated with newly emerging yellow mosaic disease of eggplant in India. Virol. J. 8, 305. http:// dx.doi.org/10.1186/1743-422X-8-305

Raj SK, Snehi SK, Khan MS, Singh R, Khan AA (2008): Molecular evidence for association of tomato leaf curl New Delhi virus with leaf curl disease of papaya (Carica papaya L.) in India. Plant Disease Notes 3, 152-155. http://dx.doi. org/10.1071/DN08059

Sanz AI, Fraile A, Garcia F, Arenal, Zhou XP, Robinson DJ, Khalid S, Butt T, Harrison BD. (2000): Multiple infection, recombination and genome relationships among begomovirus isolates found in cotton and other plants in Pakistan. J. Gen. Virol. 81, 1839-1849.

Sastry KSM, Singh SJ (1974): Effect of yellow vein mosaic virus infection on growth and yield of okra crop. Indian Phytopathol. 27, 294-297.

Saunders K, Bedford ID, Briddon RW, Markham PG, Wong SM, Stanley J (2000): A unique virus complex causes Ageratum yellow vein disease. Proc. Natl. Acad. Sci. USA 97, 890-6895. http://dx.doi.org/10.1073/pnas.97.12.6890

Saunders K, Salim N, Mali VR, Malathi VG, Briddon R, Markham PG, Stanley J (2002): Characterization of Sri Lankan 
cassava mosaic virus and Indian cassava mosaic virus: Evidence for acquisition of a DNA B component by a monopartite begomovirus. Virology 293, 63-74. http:// dx.doi.org/10.1006/viro.2001.1251

Schnippenkoetter WH, Martin DP, Willment JA, Rybicki EP (2001): Forced recombination between distinct strains of maize streak virus. J. Gen. Virol. 82, 3081-3090.

Shafiq M, Asad S, Zafar Y, Briddon RW, Mansoor S (2010): Pepper leaf curl Lahore virus requires the DNA B component of tomato leaf curl New Delhi virus to cause leaf curl symptoms. Virol. J. 7, 367. http://dx.doi.org/10.1186/1743$\underline{422 \mathrm{X}-7-367}$

Sinha SN, Chakrabarthi AK (1978): Effect of yellow vein mosaic virus infection on okra seed production. Seed Res. 6, 67-70.

Sivalingam PN, Malathi VG, Varma A (2010): Molecular diversity of the DNA- $\beta$ satellites associated with tomato leaf curl disease in India. Arch. Virol. 155, 757-764. http://dx.doi. org/10.1007/s00705-010-0634-Z

Srivastava KM, Hallan V, Raizada RK, Chandra G, Singh BP, Sane PV (1995): Molecular cloning of Indian tomato leaf curl vims genome following a simple method of concentrating the super coiled replicative form of viral DNA. J. Virol. Methods 51, 297-304. http://dx.doi.org/10.1016/01660934(94)00122-W

Tahir M, Haider MS (2005): First report of tomato leaf curl New Delhi virus infecting bitter gourd in Pakistan. Plant Pathol. 54, 807-807. http://dx.doi.org/10.1111/j.13653059.2005.01215.x

Tamura K, Peterson D, Peterson N, Stecher G, Nei M, Kumar S (2011): MEGA5: Molecular evolutionary genetics analysis using maximum likelihood, evolutionary distance, and maximum parsimony methods. Mol. Biol. Evol. 10, 1093. http://dx.doi.org/10.1093/molbev/msr121

Tiwari AK, Sharma PK, Khan MS, Snehi SK, Raj SK, Rao GP (2010): Molecular detection and identification of tomato leaf curl New Delhi virus isolate causing yellow mosaic disease in Bitter gourd (Momordica charantia), a medicinally important plant in India. Medicinal
Plants 2, 117-123. http://dx.doi.org/10.5958/j.09754261.2.2.018

Uppal BN, Varma PM, Capoor SP (1940): Yellow vein mosaic of bhendi. Curr. Sci. 9, 227-228.

Varma A, Malathi VG (2003): Emerging geminivirus problems: A serious threat to crop production. Annu. App. Biol. 142, 145-164. http://dx.doi.org/10.1111/j.1744-7348.2003. tb00240.x

Venkataravanappa V, Reddy CNL, Jalali S, Krishna Reddy M. (2013a): Molecular characterization of a new species of begomovirus associated with yellow vein mosaic of bhendi (Okra) in Bhubhaneswar, India. Eur. J. Plant Pathol. 136, 811-822. http://dx.doi.org/10.1007/s10658013-0209-4

Venkataravanappa V, Reddy CNL, Devaraju A, Jalali S, Reddy MK (2013b): Association of cotton leaf curl Bangalore virus with yellow vein mosaic disease of okra is further evidence for natural recombination of begomoviruses in India. Ind. J. Virol. 24, 188-198. http://dx.doi.org/10.1007/ s13337-013-0141-4

Venkataravanappa V, Reddy CNL, Swaranalatha P, Jalali S, Briddon RW, Krishna Reddy M (2011): Diversity and phylogeography of begomovirus-associated beta satellites of okra in India. Virol. J. 8, 555. http://dx.doi.org/10.1186/1743-422X-8-555

Venkataravanappa V, Reddy CNL, Jalali S, Krishna Reddy M (2012a): Molecular characterization of distinct bipartite begomovirus infecting bhendi (Abelmoschus esculentus L.) in India. Virus Genes 44, 522-535. http:// dx.doi.org/10.1007/s11262-012-0732-y

Venkataravanappa V, Reddy CNL, Swarnalatha P, Devaraju A, Jalali S, Krishna Reddy M (2012b): Molecular evidence for association of Cotton leaf curl Alabad virus with yellow vein mosaic disease of okra in North India. Arch. Phytopathol. Plant Prot. 1-19.

Zepeda CH, Ali M, Idris, Carnevali G, Brown JK, Valenzuela OAM, (2007): Molecular characterization and phylogenetic relationships of two new bipartite begomovirus infecting malvaceous plants in Yucatan, Mexico. Virus Genes 35, 369-377. http://dx.doi.org/10.1007/s11262-007-0080-5 